\title{
EFFECTS OF DIFFERENT STAGES OF MATURITY AND POSTHARVEST TREATMENTS ON THE EXTENSION OF SHELF LIFE AND QUALITY OF BANANA
}

\author{
Md. Abu Abdullah Al MUZAHID ${ }^{1}$, Most. Mahbuba KHANUM ${ }^{2, *}$, \\ Md. Ferdous MONDAL ${ }^{1}$
}

*E-mail: mahbuba.bari27@gmail.com

Received: Oct. 29, 2020. Revised: Dec. 22, 2020. Accepted: Dec. 29, 2020. Published online: Jan. 29, 2021

\begin{abstract}
An experiment was carried out in the Laboratories of the Departments of Horticulture and Biochemistry and Molecular Biology, Bangladesh Agricultural University, Mymensingh, during the period from $23^{\text {rd }}$ April to $10^{\text {th }}$ May 2015. The two factors experiment was conducted for extension of shelf life and quality of banana under different postharvest treatments. The first factor was stages of maturity which had three maturity stages, viz.: 1) hard green $\left.\left(S_{1}\right), 2\right)$ pale green $\left(S_{2}\right)$ and optimum maturity stage $\left(\mathrm{S}_{3}\right)$. The second factor was postharvest treatments, which had five treatments, viz.: 1) control (room temperature), 2) keeping fruits in perforated plastic bag, 3) keeping fruits in perforated plastic bag containing $\mathrm{KMnO}_{4}$, 4) fruits treated with hot water for $5 \mathrm{~min}$ at $50^{\circ} \mathrm{C}$ and then kept in plastic bag containing $\mathrm{KMnO}_{4}$, and 5) fruits precooling for $30 \mathrm{~min}$ at $5^{\circ} \mathrm{C}$ and then kept in plastic bag containing $\mathrm{KMnO}_{4}$. The pulp
\end{abstract}

to peel ratio, total soluble solids, total sugar, reducing sugar, titratable acidity, were greater when fruits were harvested at optimum maturity stage than hard green stage. Total soluble solids, total sugar, reducing sugar were increased with storage duration, but increasing trend was slower when fruits were pre-cooling at $5^{\circ} \mathrm{C}$ for $30 \mathrm{~min}$ and kept in plastic bag containing $\mathrm{KMnO}_{4}$. The longest shelf life of banana fruits (19 days) was observed when hard green stages fruits pre-cooling at $5^{\circ} \mathrm{C}$ for $30 \mathrm{~min}$ and kept in plastic bag containing $\mathrm{KMnO}_{4}$ and the minimum shelf life (5.87 days) was observed in the combination of optimum maturity stage + control. So, it may be concluded that precooling for $30 \mathrm{~min}$ at $5^{\circ} \mathrm{C}$ and then kept in plastic bag containing $\mathrm{KMnO}_{4}$ treatment should be used for extending shelf life and quality of banana.

Keywords: maturity; banana; $\mathrm{KMnO}_{4}$; postharvest; storage.

\footnotetext{
${ }_{1}^{1}$ Department of Horticulture, Bangladesh Agricultural University, Mymensingh, Bangladesh

${ }^{2}$ Agronomy Division, Agricultural Research Station, BARI, Rajbari, Dinajpur, Bangladesh
} 


\section{INTRODUCTION}

Banana is the major horticultural crop in the tropical region. It is an economically very important fruit. Banana is available throughout the year in Bangladeshi market. Banana is unique for its high calories and nutritive values. It contains five times the extra vitamin $\mathrm{A}$ and iron, compared to apples, four times the amount of protein, three times the amount of phosphorus, half the amount of carbohydrates, and other vitamins and minerals (Gasster, 1963). It is also possible to cook different items from banana, such as banana chips, banana figs, flour, powder, jam candy, dehydrated slices, etc. As a tropical and highly perishable fruit banana, its postharvest losses are often high. The postharvest scenario is a matter of serious concern for a developing country like Bangladesh. Since it is a fragile, perishable fruit, It can not be stored after harvesting for a lengthy period of time. Bangladesh, annually losses a huge amount of money every year due to shorter postharvest life of banana. Postharvest fruit loss due to insect infection is a significant concern worldwide. Banana is a consumable fruit and its post harvest losses range from 25-50\% (Amiruzzaman, 1990).

In Bangladesh, banana occupied 128780 hectares of land and total production was about 750450 metric tons, which is considerably a low yield, compared to other countries. If that amount of fruit were equally distributed among the total people of Bangladesh, the per capita availability of fruits would be far below the recommended level (100 g). Bananas are typical climacteric fruits, which ripen with increasing rate of respiration coupled with ethylene production. The perishability of the fruit is related to adverse physiological changes, weight loss due to respiration and transpiration, pulp softening and loss of resistance to microbial attack. Thus, due to a high degree of post-harvest loss, the per capita supply of fruit is further decreased. Reducing post-harvest losses by extending the shelf life of fruit can help to improve the situation.

The prolonging of shelf life of a fruit consists of slowing down the process leading to ripening, and if possible, stopping the degradation and fermentation changes that causes senescence after ripening. Changes in the physico-chemical properties occur during different stages of ripening. Softness, sweetness of flesh skin color, flavor vary between stages among the varieties. Postharvest loss of fresh fruit is one of the important problems in the tropics. Since it is a perishable fruit, a huge quantity of it goes waste due to lack of proper postharvest handling, storage and ripening. In Bangladesh, a considerable amount of banana is being spoiled due to prevailing high temperature and humidity. Its edible and marketable quality deteriorates rapidly after ripening. Banana fruits are very susceptible to many fungal diseases, namely anthracnose causing enormous loss of fruit quality. Reduction of postharvest losses by 


\section{POSTHARVEST TREATMENTS ON THE EXTENSION OF SHELF LIFE AND QUALITY OF BANANA}

prolonging the shelf life of banana can improve the present situation of spoilage. It may be done with some physical and chemical measure, such as storing in polythene bag (perforated and non-perforated) with $\mathrm{KMnO4}$, pre-cooling and hot water treated with $\mathrm{KMnO} 4$. Again, maturity stages of fruits also influence shelf life and fruit quality of banana. Hence, the present study was conducted to identify an appropriate maturity stage for the reduction of post-harvest spoilage, extension of storage period and improvement of banana quality with various post-harvest treatments.

\section{MATERIALS AND METHODS}

The study was designed from April to May 2014 at the laboratories of the Department of Horticulture and Biochemistry and Molecular Biology of Bangladesh Agricultural University, Mymensingh. One banana variety, namely Sabri, was selected as experimental material for the experiment. The banana fruits, which were used in the experiment, were collected from farmer's field at Madhupur Upazilla in Tangail district. Three types of matured fruits, viz. hard green, pale green and optimum matured were harvested for the experiment. The experiment was consisted of two factors. The first factor was stages of maturity, which had three maturity stages, viz.: 1 ) hard green $\left.\left(S_{1}\right), 2\right)$ pale green $\left(S_{2}\right)$ and optimum maturity stage $\left(\mathrm{S}_{3}\right)$. The second factor was postharvest treatments, which had five treatments, viz.: 1) control (room temperature), 2) keeping fruits in perforated plastic bag, 3) keeping fruits in perforated plastic bag containing $\mathrm{KMnO}_{4}$, 4) fruits treated with hot water for $5 \mathrm{~min}$ at $50^{\circ} \mathrm{C}$ and then kept in plastic bag containing
$\mathrm{KMnO}_{4}$, and 5) fruits pre-cooling for $30 \mathrm{~min}$ at $5^{\circ} \mathrm{C}$ and then kept in plastic bag containing $\mathrm{KMnO}_{4}$. The two-factor experiment was designed in a completely randomized design with three replications. Each treatment comprised three replications of ten fingers. Mature hard green, pale green and optimum mature, these three stages of banana of more or less uniform size, shape and color were picked. A total of four hundred and fifty bananas were selected for conducting the experiment. The banana fruits selected were randomly allocated to the postharvest treatments. After treatment, the fruits were placed on brown paper, that were previously already arranged on the laboratory table at room temperature.

Data collected from the experiment were statistically analyzed by analysis of variance. The significance of difference among the means was tested by DMRT at 5 and $1 \%$ level of probability. The following parameters were analyzed.

Pulp to peel ratio: The pulp to peel ratio was calculated by using the following formula: Pulp to peel ratio $=$ Weight of the pulp of fruit / Weight of peel $\times 100$

Dry matter content. The percentage of dry matter content of the pulp was calculated from the data obtained during the estimation of moisture content using the following formula: Percent dry matter $=100$ percent moisture content.

Total soluble solids (\% Brix). Total soluble solids (TSS) content of banana fruit pulp was computed by using Abbe's refractometer.

Determination of total sugar content of banana pulp: Total sugar content of banana pulp was measured calorimetrically by the Anthrone method (Jayaraman, 1981).

Determination of reducing sugar. Reducing sugar content of banana pulp was calculated by the dinitrosalicylic acid method (Miller, 1959). 
Estimation of non-reducing sugar content of pulp. Non-reducing sugar content of banana pulp was computed by using the following formula: Percent nonreducing sugar $=$ percent total sugarpercent reducing sugar

Titratable acidity of pulp. The titratable acidity of banana was measured by using the method of Ranganna (1979).

Shelf life. The storage life of banana fruits as affected by different post-harvest treatments was determined by counting the days from harvesting to the last edible point (Mondal, 2000).

Statistical analysis. The data obtained were statistically analyzed in order to determine the variations resulting from the experimental treatments, following the $\mathrm{F}$ variance tests. The significance of difference between the pair of means was determined by LSD test at $1 \%$ and $5 \%$ probability level (Gomez and Gomez, 1984).

\section{RESULTS AND DISCUSSION}

Pulp to peel ratio. The effect of stages of maturity on pulp to peel ratio of banana was observed significant in all the storage period. The maximum (3.52) and minimum (2.81) pulp to peel ratio at $12^{\text {th }}$ day were observed in the optimum maturity and hard green stage, respectively (Fig. 1). The effect of postharvest treatments on pulp to peel ratio of banana was observed significant variation in all the storage period. The maximum (2.87) and minimum (2.40) pulp to peel ratio at $9^{\text {th }}$ day were observed in the Control and Pre-cooled for $30 \mathrm{~min}$ then kept in plastic bag containing $\mathrm{KMnO}_{4}$ treatments, respectively (Fig. 2).

The combined effects of maturity stages and postharvest treatments on the banana pulp to peel ratio were found to be significant during the storage period. The maximum (3.22) and minimum (2.18) pulp to peel ratio at $9^{\text {th }}$ day were observed in the treatment combination of optimum maturity stage + control and hard green stage + pre-cooling, respectively (Table 1).

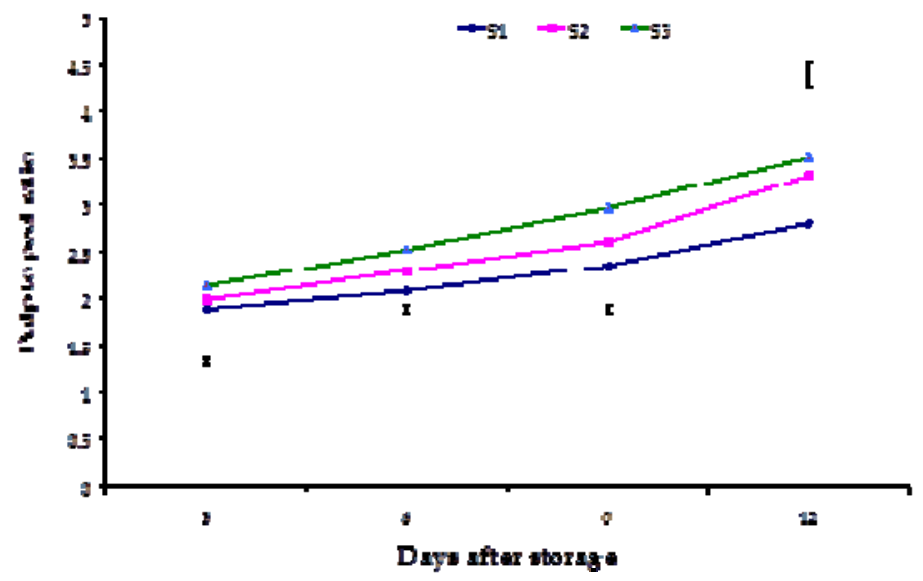

Figure 1 - Effect of maturity stages on pulp to peel ratio of banana during storage. The vertical bars indicate LSD at $1 \%$ probability level. 


\section{POSTHARVEST TREATMENTS ON THE EXTENSION OF SHELF LIFE AND QUALITY OF BANANA}

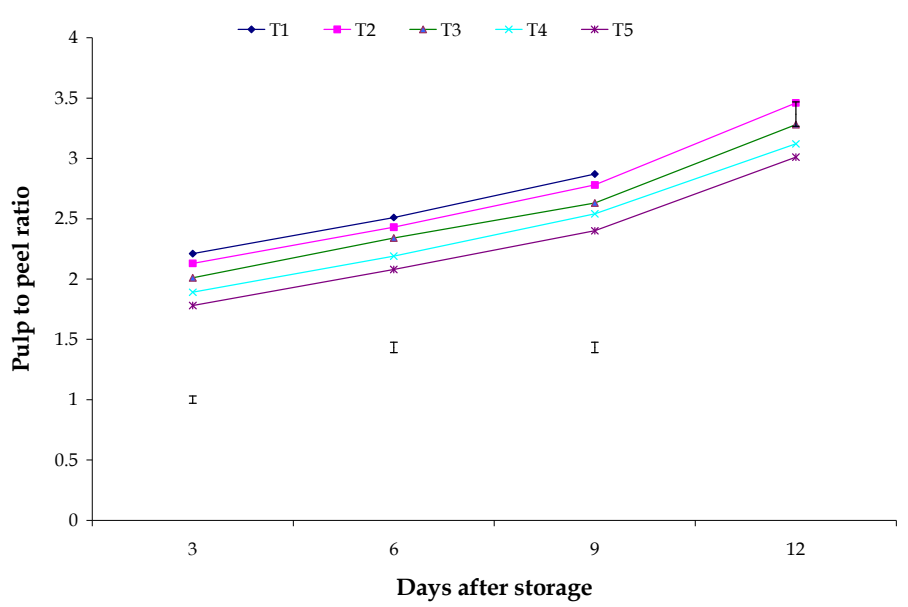

Figure 2 - Effect of postharvest treatments on pulp to peel ratio of banana during storage. The vertical bars indicate LSD at $1 \%$ probability level.

Table 1 - Combined effect of stages of maturity and postharvest treatments on pulp to peel ratio, percent dry matter content of banana at different days after treatments

\begin{tabular}{|c|c|c|c|c|c|c|c|c|}
\hline \multirow{2}{*}{$\begin{array}{l}\text { Treatment } \\
\text { combination }\end{array}$} & \multicolumn{4}{|c|}{ Pulp to peel ratio } & \multicolumn{4}{|c|}{$\%$ Dry matter content at DAS } \\
\hline & 3 & 6 & 9 & 12 & 3 & 6 & 9 & 12 \\
\hline $\mathrm{S}_{1} \mathrm{~T}_{1}$ & 2.10 & 2.27 & 2.57 & $-\overline{----}$ & 36.30 & 32.88 & 30.10 & $\begin{array}{ll}----- \\
\end{array}$ \\
\hline $\mathrm{S}_{1} \mathrm{~T}_{2}$ & 2.03 & 2.20 & 2.48 & 3.00 & 36.79 & 33.69 & 30.48 & 29.15 \\
\hline $\mathrm{S}_{1} \mathrm{~T}_{3}$ & 1.91 & 2.11 & 2.31 & 2.89 & 36.90 & 34.66 & 32.58 & 29.67 \\
\hline $\mathrm{S}_{1} \mathrm{~T}_{4}$ & 1.76 & 1.98 & 2.24 & 2.75 & 37.50 & 35.78 & 33.44 & 30.48 \\
\hline $\mathrm{S}_{1} \mathrm{~T}_{5}$ & 1.67 & 1.90 & 2.18 & 2.61 & 40.86 & 38.25 & 36.25 & 32.14 \\
\hline $\mathrm{S}_{2} \mathrm{~T}_{1}$ & 2.20 & 2.51 & 2.83 & $\begin{array}{l}----- \\
-9\end{array}$ & 34.64 & 32.44 & 29.89 & ------ \\
\hline $\mathrm{S}_{2} \mathrm{~T}_{2}$ & 2.16 & 2.49 & 2.76 & 3.50 & 35.07 & 33.25 & 30.88 & 28.58 \\
\hline $\mathrm{S}_{2} \mathrm{~T}_{3}$ & 2.00 & 2.35 & 2.67 & 3.34 & 35.17 & 34.10 & 31.30 & 29.87 \\
\hline $\mathrm{S}_{2} \mathrm{~T}_{4}$ & 1.87 & 2.19 & 2.51 & 3.27 & 35.37 & 34.77 & 32.58 & 30.39 \\
\hline $\mathrm{S}_{2} \mathrm{~T}_{5}$ & 1.71 & 2.00 & 2.26 & 3.15 & 37.59 & 36.44 & 33.47 & 31.22 \\
\hline $\mathrm{S}_{3} \mathrm{~T}_{1}$ & 2.33 & 2.75 & 3.22 & ------ & 31.78 & 30.15 & 29.15 & ------ \\
\hline $\mathrm{S}_{3} \mathrm{~T}_{2}$ & 2.20 & 2.61 & 3.10 & 3.87 & 33.10 & 30.49 & 29.41 & 27.67 \\
\hline $\mathrm{S}_{3} \mathrm{~T}_{3}$ & 2.13 & 2.56 & 2.90 & 3.61 & 33.20 & 31.25 & 29.59 & 27.89 \\
\hline $\mathrm{S}_{3} \mathrm{~T}_{4}$ & 2.05 & 2.40 & 2.86 & 3.35 & 33.30 & 31.48 & 30.33 & 28.33 \\
\hline $\mathrm{S}_{3} \mathrm{~T}_{5}$ & 1.97 & 2.33 & 2.75 & 3.26 & 35.33 & 33.22 & 31.22 & 30.14 \\
\hline $\mathrm{LSD}_{0.05}$ & 0.053 & 0.075 & 0.075 & 0.176 & 0.176 & 0.159 & 0.150 & 0.130 \\
\hline $\mathrm{LSD}_{0.01}$ & 0.071 & 0.101 & 0.101 & 0.236 & 0.236 & 0.213 & 0.201 & 0.174 \\
\hline Level of significance & ** & ** & ** & ** & ** & ** & ** & ** \\
\hline
\end{tabular}

** Significant at $1 \%$ level of probability; $\mathrm{S}_{1}=$ Hard green stage, $\mathrm{S}_{2}=$ Pale green stage,

$\mathrm{S}_{3}=$ Optimum maturity stage, $\mathrm{T}_{1}=$ Control, $\mathrm{T}_{2}=$ Fruits kept in perforated plastic bag, $\mathrm{T}_{3}=$ Fruits kept in perforated plastic bag containing $\mathrm{KMnO}_{4}, \mathrm{~T}_{4}=$ Fruits treated in hot water at $50^{\circ} \mathrm{C}$ for $5 \mathrm{~min}$ and then kept in non-perforated plastic bag containing $\mathrm{KMnO}_{4}, \mathrm{~T}_{5}=$ Fruits pre-cooled at $5^{\circ} \mathrm{C}$ for $30 \mathrm{~min}$ and then kept in non-perforated plastic bag containing $\mathrm{KMnO}_{4}$ 
Pulp to peel ratio increased day by day during storage, which was observed in this experiment. Since the increased ratio during storage can be due to changes in the concentration of sugar in the pulp relative to the peel, thus leading to a different change in osmotic pressure. Water is lost from the peel of banana both by transpiration and osmosis. As a result, the peel weight is reduced and pulp to peel ratio increases. Similar result was reported by Tripathi et al (1981). He mentioned that pulp to peel ratio increased during ripening.

Dry matter content. The effect of stages of maturity on percent dry matter content of banana was observed significant in all the storage period. The maximum (30.36\%) and minimum (28.51\%) dry matter contents at $12^{\text {th }}$ day were observed in the hard green and optimum maturity stage, respectively (Fig. 3). The effect of postharvest treatments on dry matter content of banana was observed significant in all the storage period. The maximum (33.65\%) and minimum (29.71\%) dry matter contents at $9^{\text {th }}$ day were observed in the Precooling for 30 min then kept in plastic bag containing $\mathrm{KMnO}_{4}$ and Control treatments, respectively (Fig. 4). The combined effects of stages of maturity and postharvest treatments on dry matter content of banana were observed significant during storage period. The maximum (36.25\%) and minimum (29.15\%) dry matter contents at $9^{\text {th }}$ day were observed in the treatment combination of hard green stage + pre-cooling and optimum maturity stage + control, respectively (Table 1)

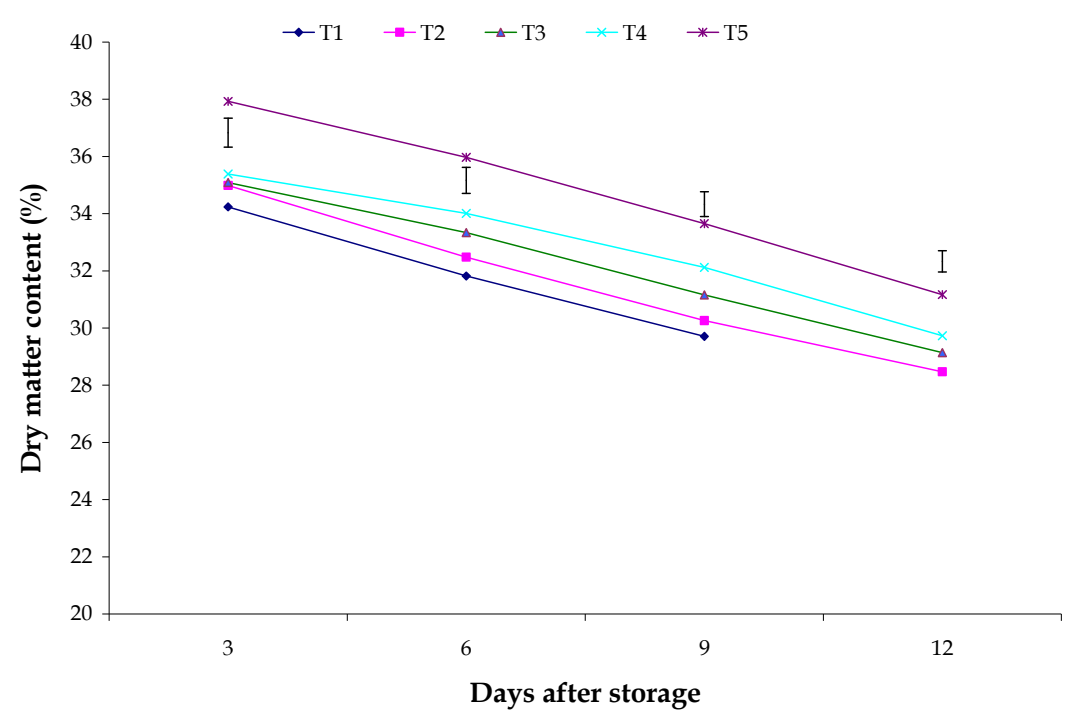

Figure 3 - Effect of maturity stages on dry matter content of banana during storage. The vertical bars indicate LSD at $1 \%$ probability level. 


\section{POSTHARVEST TREATMENTS ON THE EXTENSION OF SHELF LIFE AND QUALITY OF BANANA}

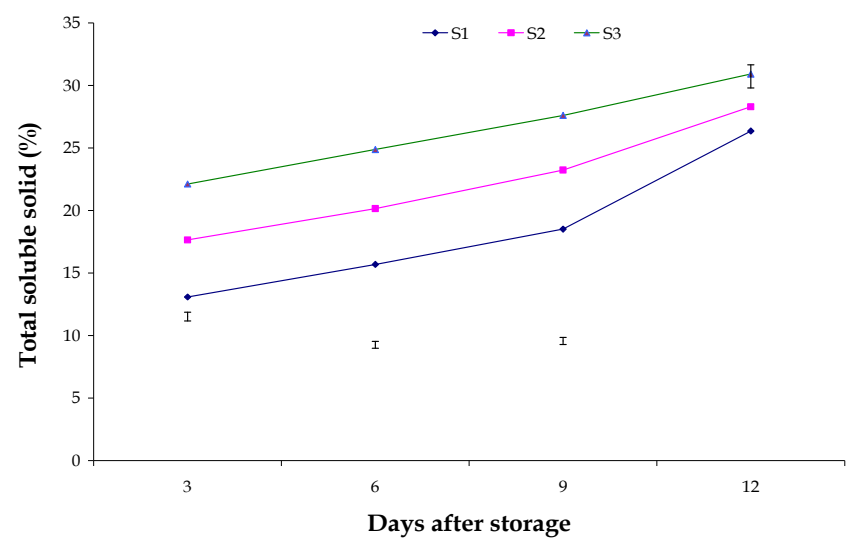

Figure 4 - Effect of postharvest treatments on dry matter content of banana during storage. The vertical bars indicate LSD at $1 \%$ probability level.

Total soluble solid (TSS). Significant variation among the effects of stages of maturity on total soluble solid (TSS) of banana was observed in all the storage period. The maximum (30.91) and minimum (26.35) TSS at $12^{\text {th }}$ day were observed in the optimum maturity and hard green stage, respectively (Fig. 5). The effect of postharvest treatments on total soluble solids of banana was observed significant variation in all the storage period. The maximum (24.66) and minimum (21.15) TSS at $9^{\text {th }}$ day were observed in the Control and Pre-cooled for $30 \mathrm{~min}$ then kept in plastic bag containing $\mathrm{KMnO}_{4}$ treatments, respectively (Fig. 6). The combined effects of stages of maturity and postharvest treatments on total soluble solid (TSS) of banana were observed significant in all the storage period. The maximum (29.33) and minimum (16.36) TSS at $9^{\text {th }}$ day were observed in the treatment combination of optimum maturity stage + control and hard green stage + pre-cooling, respectively (Table 2). Munasque and Mendoza (1990) stated that total soluble solids increased during ripening which is similar to the findings of the present study.

Total sugar content. The effect of stages of maturity on percent total sugar content of banana was observed significant during storage period. Total sugar content increased gradually during storage period, which was observed in this experiment. During ripening, banana fruits undergo physiological changes. The most striking chemical changes that occurred during the post-harvest ripening of banana fruits were starch hydrolysis and sugar accumulation. The maximum (20.96\%) and minimum (18.39\%) total sugar contents at $12^{\text {th }}$ day were observed in the optimum maturity and hard green stage, respectively (Fig. 7). Significant variation was observed among the effects of postharvest treatments on percent total sugar content of banana in all the storage period. 
M.A.A.A. MUZAHID, M.M. KHANUM, M.F. MONDAL

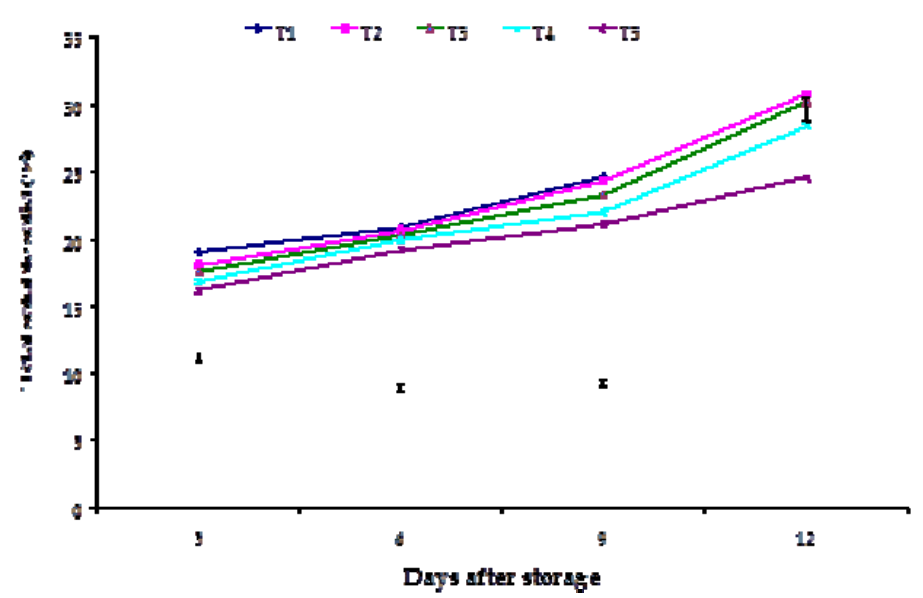

Figure 5 - Effect of maturity stages on TSS of banana during storage. The vertical bars indicate LSD at $1 \%$ probability level.

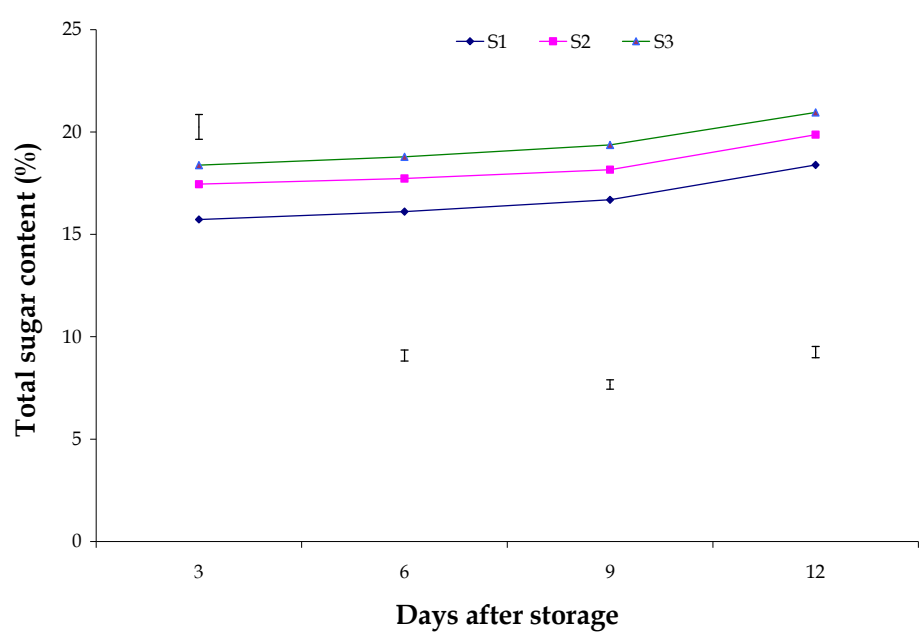

Figure 6 - Effect of postharvest treatments on TSS of banana during storage. The vertical bars indicate LSD at $1 \%$ probability level.

The maximum (20.23\%) and minimum (16.00\%) total sugar contents at $9^{\text {th }}$ day were observed in the Control and Pre-cooled for $30 \mathrm{~min}$ then kept in plastic bag containing $\mathrm{KMnO}_{4}$ treatments, respectively (Fig. 8). The combined effects of stages of maturity and postharvest treatments on percent total sugar content of banana were observed significant during storage period. The maximum (21.35\%) and minimum(14.37\%) total sugar contents at $9^{\text {th }}$ day were observed in the treatment combination of optimum maturity stage + control and hard green stage + pre-cooling, respectively 


\section{POSTHARVEST TREATMENTS ON THE EXTENSION OF SHELF LIFE AND QUALITY OF BANANA}

(Table 2). These results are supported by the findings of Bhadra and Sen (1999). They conducted an experiment

and mentioned that total sugar contents of banana pulps increased as storage period progressed.

Table 2 - Combined effect of stages of maturity and postharvest treatments on total soluble solid, total sugar content of banana at different days after treatments

\begin{tabular}{|c|c|c|c|c|c|c|c|c|}
\hline \multirow{2}{*}{$\begin{array}{l}\text { Treatment } \\
\text { combination }\end{array}$} & \multicolumn{4}{|c|}{ Total soluble solid (TSS) } & \multicolumn{4}{|c|}{ Total sugar content (\%) } \\
\hline & 3 & 6 & 9 & 12 & 3 & 6 & 9 & 12 \\
\hline $\mathrm{S}_{1} \mathrm{~T}_{1}$ & 14.33 & 16.33 & 20.33 & $\begin{array}{l}---- \\
\end{array}$ & 18.22 & 18.60 & 19.25 & $\begin{array}{c}--- \\
\end{array}$ \\
\hline $\mathrm{S}_{1} \mathrm{~T}_{2}$ & 13.33 & 16.14 & 20.11 & 29.67 & 17.25 & 17.65 & 18.10 & 20.05 \\
\hline $\mathrm{S}_{1} \mathrm{~T}_{3}$ & 13.10 & 15.60 & 18.36 & 29.11 & 15.69 & 15.97 & 16.41 & 19.41 \\
\hline $\mathrm{S}_{1} \mathrm{~T}_{4}$ & 12.44 & 15.22 & 17.41 & 26.25 & 14.33 & 14.85 & 15.33 & 17.33 \\
\hline $\mathrm{S}_{1} \mathrm{~T}_{5}$ & 12.22 & 15.15 & 16.36 & 20.36 & 13.18 & 13.50 & 14.37 & 16.75 \\
\hline $\mathrm{S}_{2} \mathrm{~T}_{1}$ & 18.66 & 20.67 & 24.33 & $\begin{array}{ll}---- \\
\end{array}$ & 19.20 & 19.55 & 20.08 & $\begin{array}{ll}---- \\
\end{array}$ \\
\hline $\mathrm{S}_{2} \mathrm{~T}_{2}$ & 18.44 & 20.33 & 24.30 & 29.75 & 18.66 & 18.95 & 19.34 & 21.50 \\
\hline $\mathrm{S}_{2} \mathrm{~T}_{3}$ & 17.60 & 20.15 & 23.15 & 29.44 & 17.58 & 17.86 & 18.20 & 20.25 \\
\hline $\mathrm{S}_{2} \mathrm{~T}_{4}$ & 17.20 & 20.14 & 22.50 & 28.75 & 16.44 & 16.74 & 17.22 & 19.25 \\
\hline $\mathrm{S}_{2} \mathrm{~T}_{5}$ & 16.33 & 19.44 & 21.89 & 25.20 & 15.38 & 15.55 & 15.97 & 18.47 \\
\hline $\mathrm{S}_{3} \mathrm{~T}_{1}$ & 24.33 & 25.77 & 29.33 & ----- & 20.04 & 20.67 & 21.35 & ----- \\
\hline $\mathrm{S}_{3} \mathrm{~T}_{2}$ & 22.60 & 25.47 & 28.66 & 32.96 & 19.22 & 19.59 & 20.14 & 22.15 \\
\hline $\mathrm{S}_{3} \mathrm{~T}_{3}$ & 22.20 & 25.33 & 28.47 & 32.14 & 18.45 & 18.95 & 19.47 & 21.47 \\
\hline $\mathrm{S}_{3} \mathrm{~T}_{4}$ & 21.10 & 24.66 & 26.34 & 30.14 & 17.33 & 17.61 & 18.22 & 20.67 \\
\hline $\mathrm{S}_{3} \mathrm{~T}_{5}$ & 20.33 & 23.10 & 25.19 & 28.40 & 16.87 & 17.11 & 17.65 & 19.55 \\
\hline $\mathrm{LSD}_{0.05}$ & 0.331 & 0.265 & 0.275 & 0.884 & 0.543 & 0.243 & 0.205 & 0.249 \\
\hline $\mathrm{LSD}_{0.01}$ & 0.444 & 0.355 & 0.369 & 1.185 & 0.728 & 0.326 & 0.275 & 0.333 \\
\hline Level of significance & $\star \star$ & $\star \star$ & $\star \star$ & $\star \star$ & $\star \star$ & ** & $\star \star$ & ** \\
\hline
\end{tabular}

** Significant at $1 \%$ level of probability; $\mathrm{S}_{1}=$ Hard green stage, $\mathrm{S}_{2}=$ Pale green stage,

$\mathrm{S}_{3}=$ Optimum maturity stage, $\mathrm{T}_{1}=$ Control, $\mathrm{T}_{2}=$ Fruits kept in perforated plastic bag, $\mathrm{T}_{3}=$ Fruits kept in perforated plastic bag containing $\mathrm{KMnO}_{4}, \mathrm{~T}_{4}=$ Fruits treated in hot water at $50^{\circ} \mathrm{C}$ for 5 min and then kept in non-perforated plastic bag containing $\mathrm{KMnO}_{4}, \mathrm{~T}_{5}=$ Fruits pre-cooled at $5^{\circ} \mathrm{C}$ for 30 min and then kept in non-perforated plastic bag containing $\mathrm{KMnO}_{4}$.

Reducing sugar content. The variation among the effects of stages of maturity on percent reducing sugar content of banana was observed significant in all the storage period. Reducing sugar also increased gradually during storage period, which was observed in this experiment. The maximum (17.56\%) and minimum (14.34\%) reducing sugar contents at $12^{\text {th }}$ day were observed in the optimum maturity and hard green stage, respectively (Fig. 9).
The effect of postharvest treatments on percent reducing sugar content of banana was observed significant variation in all the storage period. The maximum (16.08\%) and minimum $(11.26 \%)$ reducing sugar contents at $9^{\text {th }}$ day were observed in the Control and Pre-cooled for 30 min then kept in plastic bag containing $\mathrm{KMnO}_{4}$ treatments, respectively (Fig. 10). 
M.A.A.A. MUZAHID, M.M. KHANUM, M.F. MONDAL

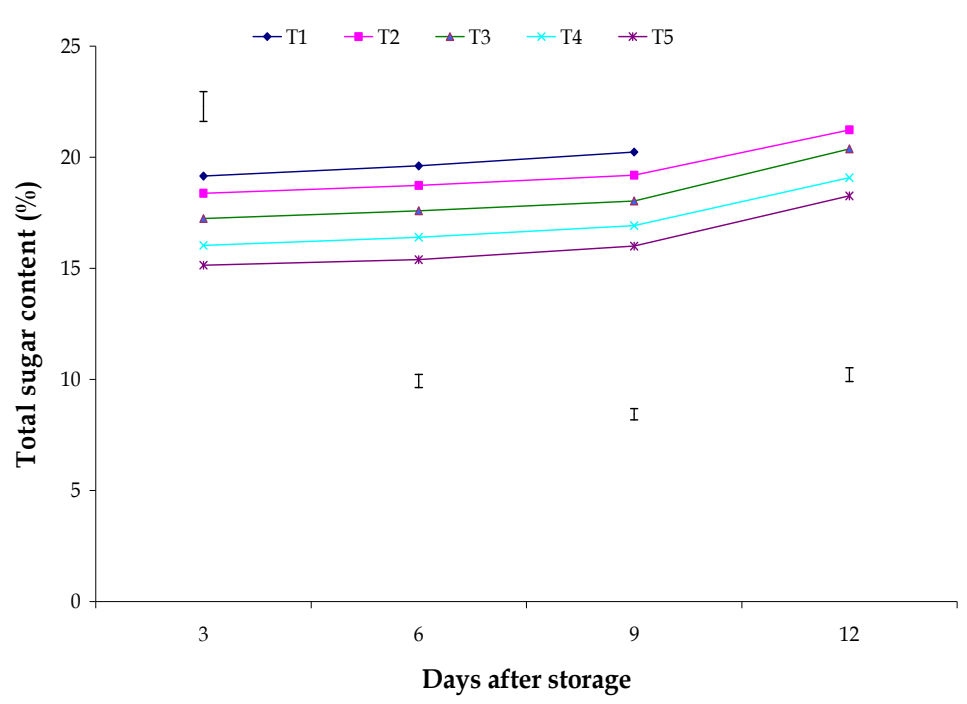

Figure 7 - Effect of maturity stages on total sugar content of banana during storage. The vertical bars indicate LSD at $1 \%$ probability level.

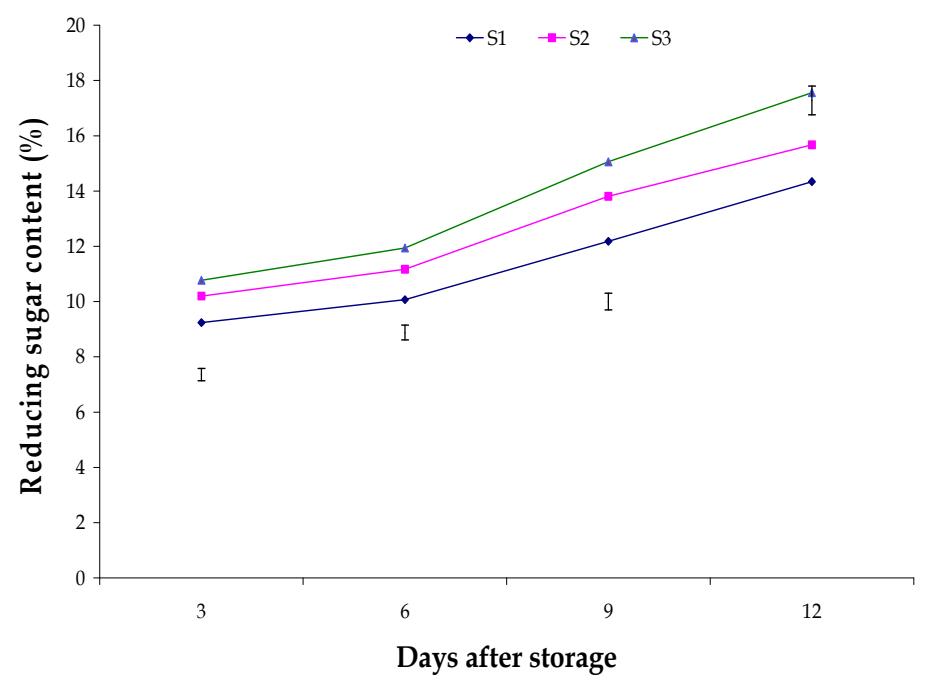

Figure 8 - Effect of postharvest treatments on total sugar content of banana during storage. The vertical bars indicate LSD at $1 \%$ probability level. 


\section{POSTHARVEST TREATMENTS ON THE EXTENSION OF SHELF LIFE AND QUALITY OF BANANA}

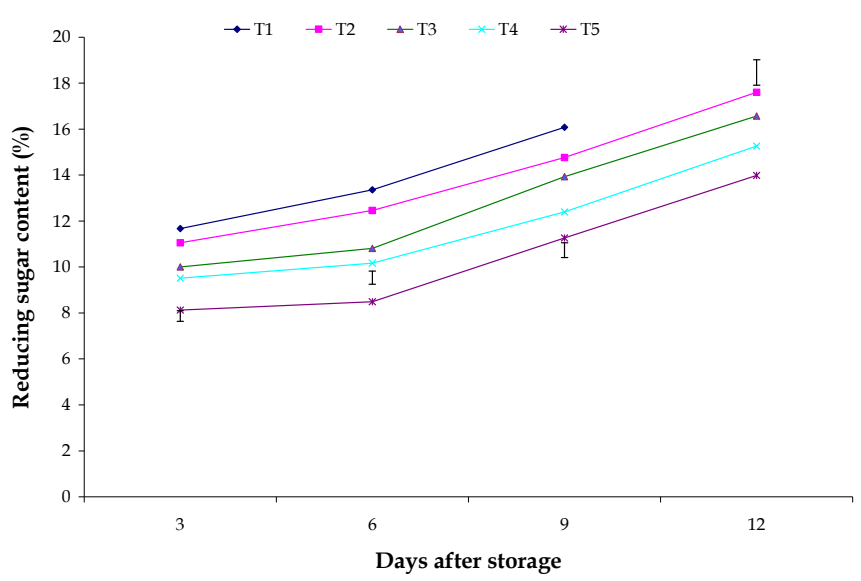

Figure 9 - Effect of maturity stages on reducing sugar content of banana during storage. The vertical bars represent LSD at $1 \%$ probability level.

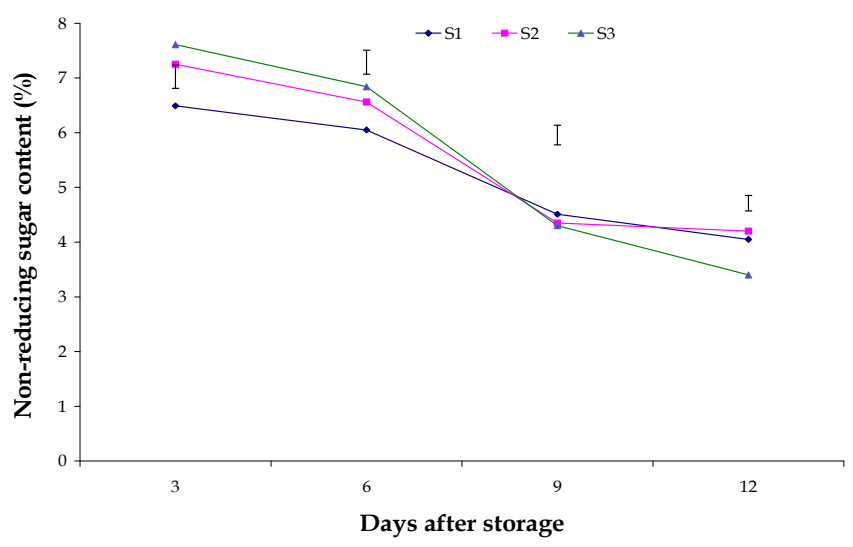

Figure 10 - Effect of postharvest treatments on reducing sugar content of banana during storage. The vertical bars indicate LSD at $1 \%$ probability level.

The increase of reducing sugar contents in banana pulp is resulted from the degradation of starch to glucose and fructose by the activities of amylase and maltase and also by conversion of some non-reducing sugar to reducing sugar. The combined effects of stages of maturity and postharvest treatments on percent reducing sugar content of banana was observed in all the storage period.
The maximum (17.69\%) and minimum (9.58\%) reducing sugar contents at $9^{\text {th }}$ day were observed in the treatment combination of optimum maturity stage + control and hard green stage + pre-cooling, respectively (Table 3).

Non-reducing sugar content. Significant variation among the effects of stages of maturity on 
percent non-reducing sugar content of banana was observed in all the storage period. Non-reducing sugar contents decreased gradually at all the day of observation in this experiment. The maximum (4.20\%) and minimum (3.40\%) reducing sugar contents at $12^{\text {th }}$ day were observed in the pale green and optimum maturity stage, respectively (Fig. 11). The effect of postharvest treatments on percent non-reducing sugar content of banana was observed significant variation during storage period. The maximum (4.73\%) and minimum $(4.10 \%)$ nonreducing sugar contents at $9^{\text {th }}$ day were observed in the Pre-cooled for $30 \mathrm{~min}$ then kept in plastic bag containing $\mathrm{KMnO}_{4}$ and keeping fruits in perforated plastic bag containing $\mathrm{KMnO}_{4}$ treatments, respectively (Fig. 12).

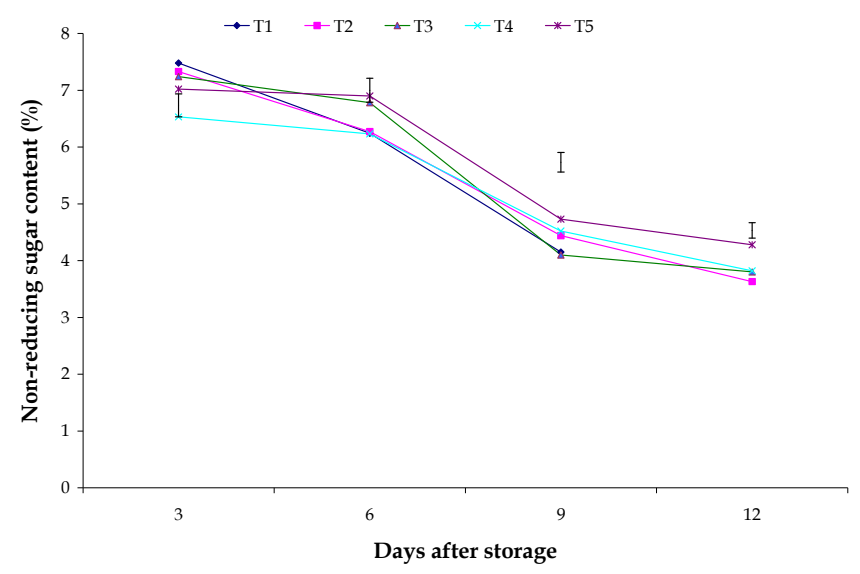

Figure 11 - Effect of maturity stages on non-reducing sugar content of banana during storage. The vertical bars indicate LSD at $1 \%$ probability level.

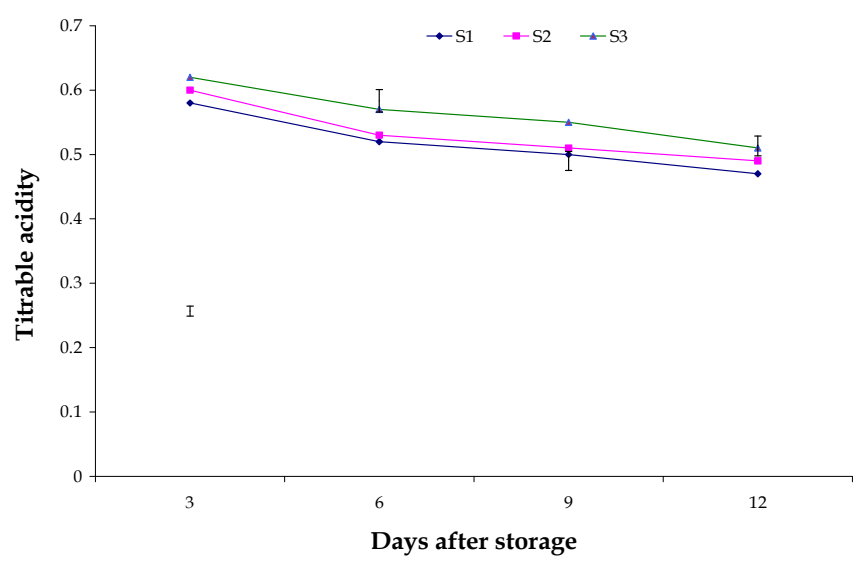

Figure 12 - Effect of postharvest treatments on non-reducing sugar content of banana during storage. The vertical bars indicate LSD at $1 \%$ probability level. 


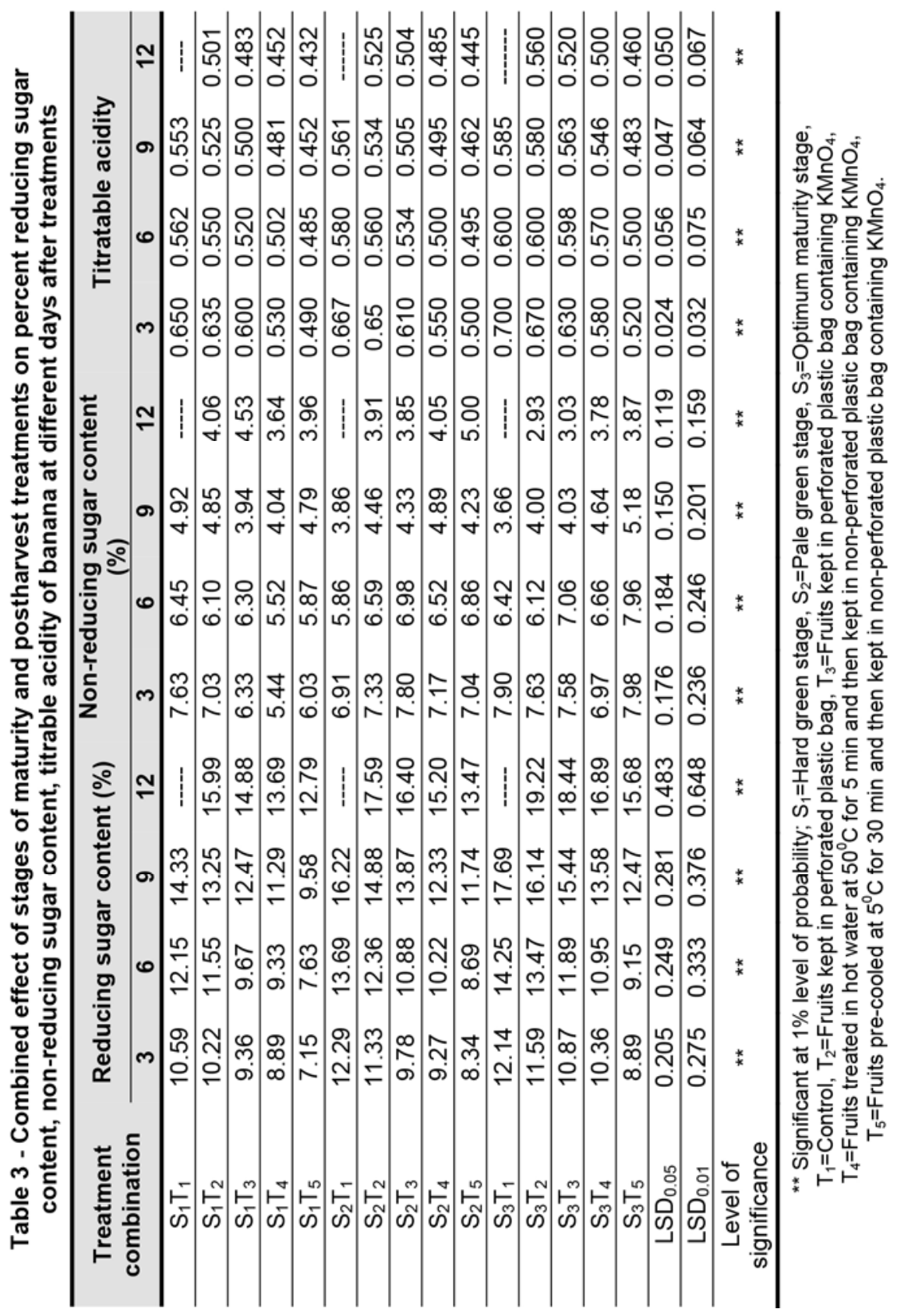


The combined effects of stages of maturity and postharvest treatments on percent non-reducing sugar content of banana were observed significant in all the storage period. The maximum (5.18\%) and minimum (3.66\%) non-reducing sugar contents at $9^{\text {th }}$ day was observed in the treatment combination of optimum maturity stage + pre-cooling and optimum maturity stage + control, respectively (Table 3 ). These results are similar by the findings of Joshi and Roy (1988). They estimated that after attaining a peak non-reducing sugar remains more or less constant.

Titratable acidity. The effect of stages of maturity on titratable acidity of banana was observed significant variation in all the storage period. The maximum (0.51) and minimum (0.47) titratable acidity at $12^{\text {th }}$ day were observed in the optimum maturity and hard green stage, respectively (Fig. 13). Significant variation among the effects of postharvest treatments on titratable acidity of banana was observed in all the storage period. The maximum (0.57) and minimum (0.47) titratable acidity at $9^{\text {th }}$ day were observed in the Control and Precooled for 30 min then kept in plastic bag containing $\mathrm{KMnO}_{4}$ treatments, respectively (Fig. 14).

From this experiment it was observed that titratable acidity gradually decreased during storage period. The combined effects of stages of maturity and postharvest treatments on titratable acidity of banana were observed significant variation in all the storage period.

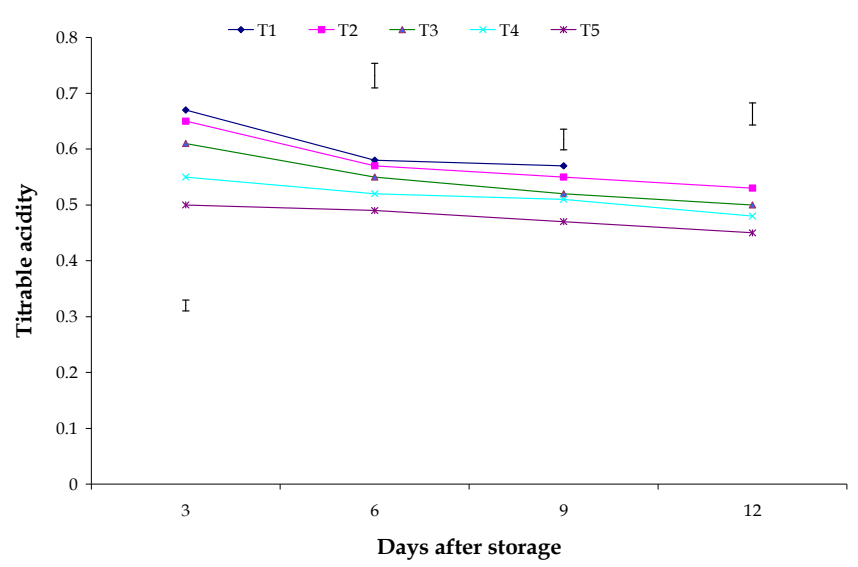

Figure 13 - Effect of maturity stages on titratable acidity of banana during storage. The vertical bars indicate LSD at $1 \%$ probability level.

The maximum (0.585) and minimum (0.452) titratable acidity at $9^{\text {th }}$ day were observed in the treatment combination of optimum maturity stage + control and hard green stage + pre-cooling, respectively (Table 3 ). 


\section{POSTHARVEST TREATMENTS ON THE EXTENSION OF SHELF LIFE AND QUALITY OF BANANA}

These results are supported by the findings of Reis et al. (2004). He stated that the result of chemical dip, calcium chloride + ascorbic acid and modified atmosphere storage reduces titratable acidity.

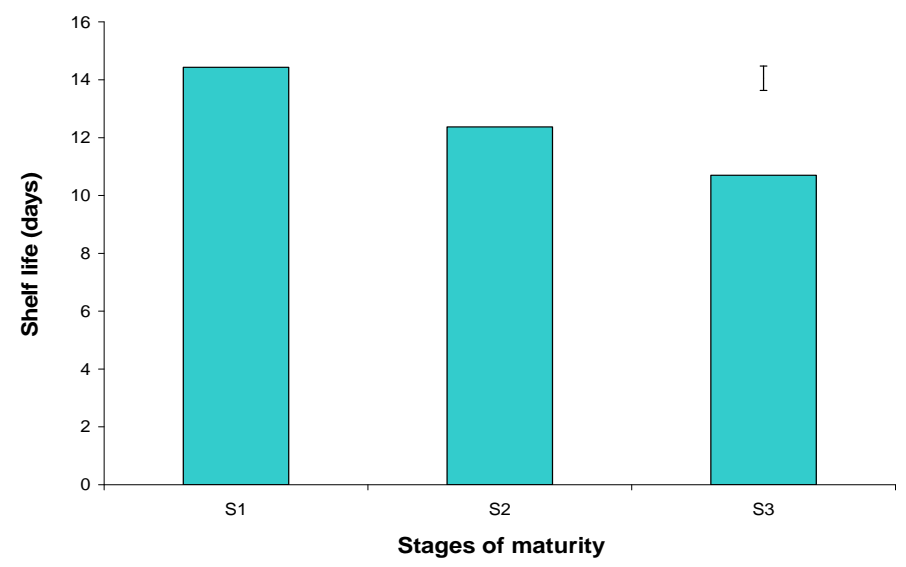

Figure 14 - Effect of postharvest treatments on titratable acidity of banana during storage. The vertical bars indicate LSD at $1 \%$ probability level.

Shelf life is the period of time which start from the time of harvesting and extend up to the start of rotting of fruit (Mondal, 2000) and it is the basic quality of fruit, as well as the most important parameter in loss of biochemical reaction of fruit. The effect of stages of maturity on shelf life of banana was observed significant variation in all the storage period. The maximum (14.43 days) and minimum (10.70 days) shelf life was observed in the hard green and optimum maturity stage, respectively (Fig. 15).

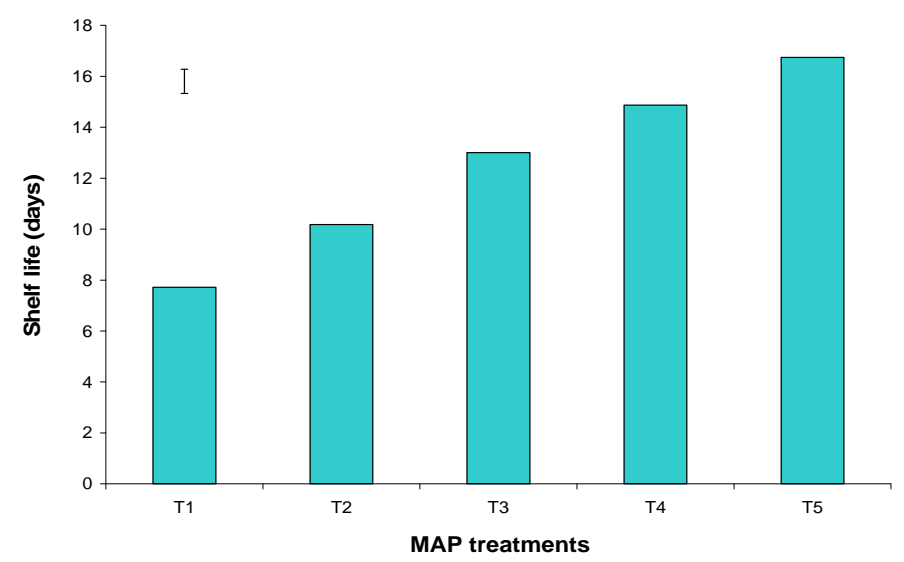

Figure 15 - Effects of maturity stages on shelf life of banana during storage. The vertical bars indicate LSD at $1 \%$ probability level. 
The effect of postharvest significant variation in all the storage treatments on shelf life of banana was observed significant variation in all the storage period. The maximum (16.74 days) and minimum (7.72 days) shelf life were observed in the Precooled for 30 min then kept in plastic bag containing $\mathrm{KMnO}_{4}$ and Control treatments, respectively (Fig. 16). The combined effects of stages of maturity and postharvest treatments on shelf life of banana were observed period. The maximum (19.33 days) and minimum (5.87 days) were observed in the treatment combination of hard green stage + pre-cooling and optimum maturity stage + control, respectively (Fig. 17). Similar results are reported by Rao and Rao (1990). He reported that color development ripening was delayed when the fruits were stored in polythene bags.

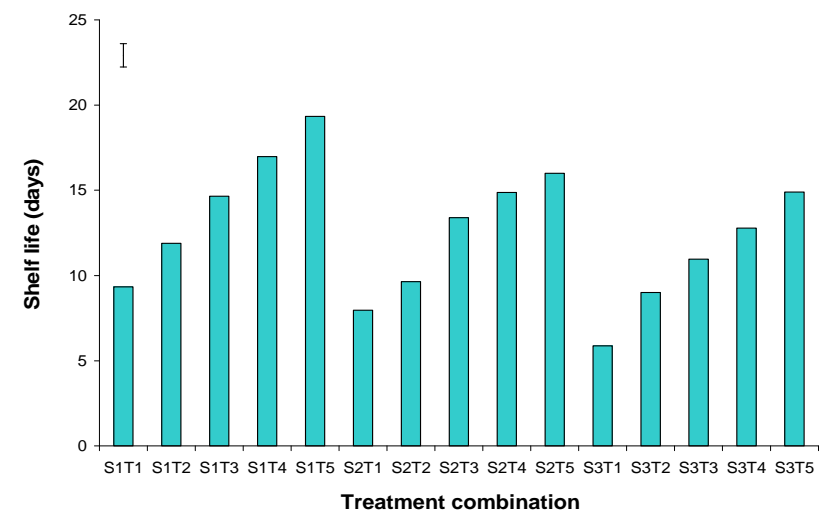

Figure 16 - Effects of postharvest treatments on shelf life of banana during storage. The vertical bars indicate LSD at $1 \%$ probability level.

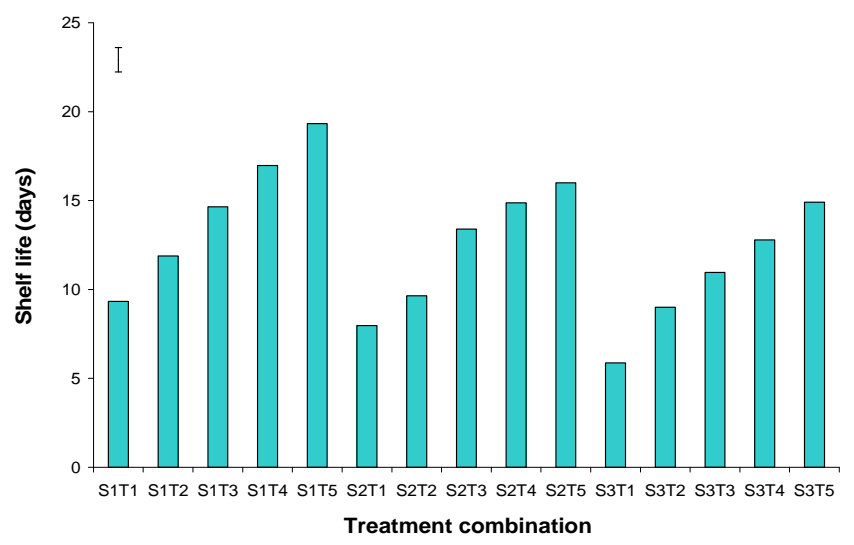

Figure 17 - Combined effects of stages of maturity and postharvest treatments on shelf life of banana during storage.

The vertical bars indicate LSD at $1 \%$ probability level. 


\section{POSTHARVEST TREATMENTS ON THE EXTENSION OF SHELF LIFE AND QUALITY OF BANANA}

\section{CONCLUSIONS}

It can be concluded from the results of this study that mature hard green stage performed best among all the mature stage. Pre-cooling and then kept in plastic bag containing $\mathrm{KMnO}_{4}$ treatment performed better than the control. Among the two factors, the best performance was found in precooling and then kept in nonperforated plastic bag containing $\mathrm{KMnO}_{4}$ in all cases. So, pre-cooling for $30 \mathrm{~min}$ at $5^{\circ} \mathrm{C}$ and then kept in plastic bag containing $\mathrm{KMnO}_{4}$ treatment is the best postharvest treatment for extending shelf life, quality and reduction of spoilage of banana.

\section{REFERENCES}

Amiruzzaman, M. (1990). Postharvest handling and processing of fruits and vegetables. In: Kitchen Gardening and Homestead Production Activities. CIRDAP Action Res., Series No. 11, p. 22.

Bhadra, S. \& Sen, S.K. (1997). Postharvest storage of custard apple (Annona squamosa L.) fruit variety local green under various chemical and wrapping treatments. Environ. Ecol., 4: 322-228.

Gasster, M. (1963). The banana in geriatric and low-calorie diets. Geriatrics, 18: 782-786.

Gomez, K.A. \& Gomez, A.A. (1984). Statistical procedures for agricultural research. John Wiley and Sons, New York, pp. 97-129.

Jayarman, J. (1981). Laboratory manual in biochemistry. Wiley Eastern Ltd, New Delhi, India, p. 546.
Joshi, G.D. \& Roy, S.K. (1988). Influence of maturity, transport and cold storage on biochemical composition of Alphonso mango fruit. Journal of Moha Agricultural University, 13(1): 12-15.

Miller, G.L. (1959). Use of dinitrosalicylic acid reagent for determination of reducing sugars. Anal.Chem., 31, 426-428, DOI: 10.1021/ac60147a030

Mondal, M.F. (2000). Production and storage of fruits (in Bengali). Published by Mrs. Afia Mondal: BAU Campus, Mymensingh-2202, p. 312.

Munasque, V.S. \& Mendoza, D.B. (1990). Developmental physiology and ripening of 'Senorita' banana (Musa sp. L.) fruits. ASEAN Food of J., 5(4): 152-157.

Ranganna, S. (1979). Manual analysis of fruit and vegetable products. Tata McGraw-Hill Publishing Company Limited, New Delhi, p. 112.

Rao, D.M. \& Rao, M.R. (1990). Postharvest changes in banana cV. Robusta. Indian J.Hortic., 36(4): 387-393.

Reis, C.M.F., Vilas Boas, E.V. de B., Boari, C.A. \& Piccoli, R.H. (2004). Quality and shelf life of fresh-cut banana 'Prata'. Ciênc.Agrotec., 28(3): 696-702, DOI: 10.1590/S141370542004000300029

Tripathi, V.K., Ram, H.B., Jain, S.P. \& Sing, S. (1981). Changes in development banana fruits. Program of Horticulture, 13(1): 45-53. 